\title{
ASSESSMENT OF THE ROLE OF ACCOUNTING INFORMATION ON EFFECTIVE INVESTMENT DECISION - THE CASE OF BANQUE POPULAIRE DU RWANDA ATLASMARA
}

\author{
James Hodari ${ }^{i}$ \\ PhD Student, \\ Chhatrapati Shahu Ji Maharaj University, \\ Kanpur, India
}

\begin{abstract}
:
The purpose of this study is to assess the role of accounting information on effective investment decisions at Banque Populaire du Rwanda Atlasmara. The target population was 50 staff members. The study used a primary method that involved questionnaires. Secondary methods of data collection involved a desk review of relevant materials. Data collection was then analyzed by using SPSS software. The study indicated a significant correlation between accounting information and investment decisions and all rely on information for an investment decision. It was seen from the analysis of responses, 83\% argued always use accounting information for investment. It was revealed that the quality of accounting information in terms of its accuracy, adequacy, reliability, and mode of disclosure is a pertinent element of efficiency of investment decision making. The study recommends that commercial banks should use accounting always to increase the accuracy of their investment decision-making. The study recommends that Banque Populaire du Rwanda should consult the accounting information before making investment decisions and all interested parties to accounting information should use necessary financial ratios analysis for an investment decision. The study concludes that there is a significant correlation between accounting information and investment decision.
\end{abstract}

JEL: M10; M41; R42

Keywords: accounting information, decision, decision making, investment, investment decision

${ }^{i}$ Correspondence e-mail: thodali83@gmail.com, 


\section{Introduction}

From the 1960s, all business organizations prepare an income statement. Also, commercial banks prepare accounting statements. Accounting information provides a window for those external decision-makers like investors in a company, to view the consequences of those decisions made (Berisha, 2012). Accounting information was used to supply information to invest wealth and manager in investing activities in a business. Previous studies found that some earlier investment decision-making need not be thought of as the best example by using accounting information. The accounting information performs a crucial role in the investment decision. In a study conducted by Hall (2010), accounting information is expressed in monetary terms and it shows the bank profit through the balance sheet, but also it is analyzed to clarify the profitability of the organization to determine the managerial efficiency.

Investment decisions depend on the financial strength and dividend-paying capacity of the business. Thus, this accounting information has been regarded as a service activity since it provides qualitative and quantitative information about economic activities. However, existing literature reviews show that investors have been lacking reliable and relevant information needed to highlight the company's performance and financial position or even the information they get is not complete as it can be. This causes ambiguity and uncertainty that lead them to fail in their investment decisions. Investors who invest in business judge the financial position and solvency of concern by analyzing reliable data which helps in evaluating the performance. They analyze them before making decisions. Different managers need accounting information to make important investment decisions. In this connection, accounting information is a primary role in providing useful accounting information for investment decision-making purposes; therefore, evaluating the relationship between accounting information and investment decision is crucial.

Richard (2010) gave the following reasons for failure in making good and effective rational investment decisions: decision objectives often are vague, conflicting, and lack consensus, managers and investors are not aware of the problems or opportunities that exist in an organization; national procedures are not always used and when they are confined to a simplistic view of the problem that does not capture the complexity of real organizational events; managers and investor's search for alternatives are limited because of human, information and resource constraints; and many investors and managers settle for a satisfying rather than a maximizing solution.

This prompted the researcher to assess the role of accounting information on effective investment decisions where investors and managers have to make rational, effective investment activity decisions basing on accounting information. The general objective of this research is to assess the role of accounting information on effective investment decisions. 


\section{Objectives}

The specific objective of this study is:

1) To analyze the accounting information parameters applied by Banque Populaire du Rwanda Atlasmara.

2) To assess the level of effectiveness of investment decision making in Banque Populaire du Rwanda Atlasmara.

3) To establish the relationship between accounting information and investment decision in Banque Populaire du Rwanda Atlasmara.

\section{Literature Review}

The theoretical and conceptual framework includes dependent variables and independent variables. The independent variable is the accounting information. A dependent variable is an investment decision that may be efficient or inefficient, effective or ineffective depending on the factors which are to be tested scientifically. Accounting information provides past, recent, and future-oriented information to guide decisionmakers to measure the risk and return before taking any decision regarding an organization's activities.

For this study, the accounting theory, the theory of GAAP, the theory of decision, and the theory of investment were adopted due to their relevance in assessing the role of accounting information on investment decisions. As stated by Handayani (2011), accounting theory may be despite as logical reasoning that it assists to assess accounting practices. Accounting theory helps develop new accounting practices and procedures. Further, accounting theory can be thought of as the logical reasoning that helps evaluate and guide accounting practices. Accounting theory, as regulatory standards evolve, also helps develop new accounting practices and procedures.

Generally, financial statements are prepared to base on accepted accounting principles (called GAAPs). These principles guide how to prepare financial statements. According to Sotiraq (2010), the sources of accounting principles and practices are the American Institute of Certified Public Accountants (AICPA), FASB, and the Security Exchange Commission (SEC). Others are IASC, the International Federation of Accountants (IFAC), and the American Accounting Association (AAA). This principle states that all accounting information should be relevant, reliable. What this essentially means is that all financial statements need to be accurate and stick to the generally accepted accounting principles (GAAP). By supporting GAAP, it allows the preparation of financial statements to be both regular and similar to a company's past financials, as well as the financials of other companies.

Moreover, the word decision means to decide, to conclude. It represents a course of action about what must be done. According to Stickney, et al. (2010), define decision as a choice whereby a person concludes about a situation. Sherlekar elaborates further that decision is the act of determining in one's mind upon an opinion or a course of action 
from two or more alternative courses of action. It encompasses the body of knowledge used to support the decision-making process of choosing investments for various purposes. It includes portfolio theory, the capital asset pricing model, arbitrage pricing theory, the efficient market hypothesis, and rational pricing (Xhelili, et al., 2015).

\section{Empirical Review}

Xhelili et al. (2015) stated that "effective decision is well done when decision-makers are keenly aware of the importance of properly defining the situation and understanding it". To assess the consequences of decisions regarding investment, investors and managers need information. However, managers try to obtain information about decision alternatives that will reduce decision uncertainty. According to Berisha (2012), accounting information helps investors assess the effectiveness and efficiency of the business in helping them estimate the return that can be expected from investing in a business and the amount of risk associated with their investment. The return on investment shows the amount of profits earned by a business that could be paid to owners which can be distributed or reinvested to acquire additional resources; the business uses additional resources to earn more profit by expanding its size or new location or product lines.

Investors who invest in business judge the financial position and solvency of concern by providing reliable cost data which helps in evaluating the performance. They analyze them before making decisions. This attracts investors due to the efficient accounting information system. Good decision making is a vital part of good management because decisions determine how the organization solve its problems, allocate resource and accomplish its objectives. According to Richard (2010), every decision situation can be organized on a scale according to the availability of information and the possibility of failure, the author devised four positions on the scale which are certainty, risk, uncertainty, and ambiguity. However, an effective decision maker should not neglect to consider past events and their outcomes which are found in accounting information. Knowledge and what happened in past can aid in deciding because history may shed considerable light on what the future is likely to hold. Thus, one of the fundamental inputs to decision making is dependable and relevant data which include costs, revenues, assets, liabilities, and owners' equity.

According to Berisha (2012), managers as internal decision-makers use financial accounting information in addition to managerial accounting information in their decision; they are also concerned about the effect of financial accounting information on their decision of the stakeholders. Managers also decide how much to invest in resources and the types of resources to acquire. Often these decisions involve a large amount of money and have a major effect on the future position of an organization. These decisions affect the future profitability, supply of goods and services, and future return to owner and creditor. In making investment decisions, managers need information for predicting the demand for goods and services. They need to know which product will be added 
when they will be demanded, how much will be demanded and the price customers are willing to pay.

\section{Independent variable}

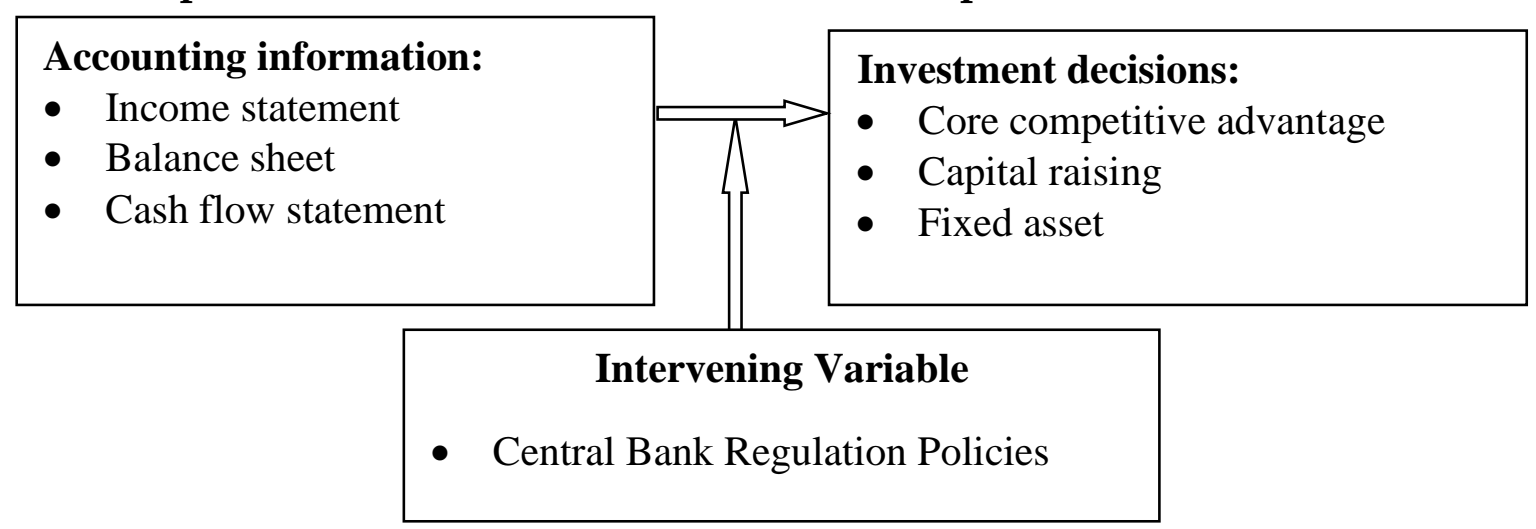

Figure 1: The Conceptual Framework: Relationship between Independent Variable and Dependent Variable

\section{Materials and Methods}

This study used a survey research method since this is both a qualitative and quantitative study on the role of accounting information on effective investment decisions using a case of Banques Populaires du Rwanda Atlasmara as a case study located in Kigali city. The researcher used both primary and secondary sources of data. Primary data was obtained from employees of Banques Populaires du Rwanda Atlasmara through a questionnaire. Sources of secondary data were obtained from Banques Populaires du Rwanda documents as well as electronic data.

The study used questionnaires and desk review. A questionnaire was delivered to respondents. The study used this method to get information from the employees of BPR Atlasmara because they are assumed to have the necessary information on investment decisions. A desk review is the data collection process that is based on reading books and other documents relevant to the study. The study visited libraries to read a great deal about the subject he has undertaken to acquire the background and to find out information from other studies on a similar topic. Other documents considered were structure, manual of procedures, BPR Atlasmara reports, and documents.

In this study, a purposive sampling technique was used in selecting respondents. Some of the employees affiliated with the following departments that are Finance, and Directorate that is in the number of 50 respondents who were considered as a sample, were interviewed and answered the provided questionnaires. The study used simple random sampling to select a sample size of 50 staff to reduce the possibility of business so that all departments were involved in the sample and correct information was collected. Busara, (2012) defines a sample size as several items to be selected from the universe to constitute a sample. During data processing, relevant data to the objectives of the study was considered and transformed into meaningful information for easy 
interpretation and understanding. This process was done through editing, coding, and tabulation. The study employed both qualitative and quantitative analysis to achieve the objectives of the study.

\section{Results and Discussion}

The study was carried out on BPR Atlasmara which has a strong capital base of RWF 15800000000 and 617332 shareholders, $65 \%$ of the equity is held by former cooperative members and $35 \%$ is held by RABOBANK. Neo-institutional theory argues that the use of accounting information is shaped by environmental factors with similar environmental factors leading to similar applications of accounting information (Berisha,2012). However, our study emphasizes that these environmental factors need to be evaluated with other endogenous factors such as the bank structure and managers' preferences.

For this work, the researcher assessed the role of accounting information on investment decisions at BPR Atlasmara through the income statement, balance sheet, and cash flow statement. To analyze the effect of accounting information the study used income statements on investment decisions, the range was Strongly Agree (5) and Strongly Disagree (1). The standard deviation of $>0.9$ implies a significant variation in the application of variables.

Table 1: Use of Accounting information for investment decision at BPR Atlasmara

\begin{tabular}{|c|c|c|c|c|c|c|c|}
\hline $\begin{array}{l}\text { Kind of Accounting } \\
\text { Information }\end{array}$ & $\begin{array}{l}\text { Strongly } \\
\text { Disagree }\end{array}$ & Disagree & $\begin{array}{l}\text { Not } \\
\text { Sure }\end{array}$ & Agree & $\begin{array}{l}\text { Strongly } \\
\text { Agree }\end{array}$ & \multirow[t]{2}{*}{ Mean } & \multirow{2}{*}{$\begin{array}{l}\text { Standard } \\
\text { Deviation }\end{array}$} \\
\hline & $\%$ & $\%$ & $\%$ & $\%$ & $\%$ & & \\
\hline \multicolumn{8}{|l|}{ Low-Cost Leadership } \\
\hline $\begin{array}{l}\text { We use income statement } \\
\text { in making investment } \\
\text { decision }\end{array}$ & 4.0 & 2.0 & 12.0 & 36.0 & 46.0 & 4.180 & 1.003 \\
\hline $\begin{array}{l}\text { We use balance sheet in } \\
\text { making investment } \\
\text { decision }\end{array}$ & 2.0 & 4.0 & 18.0 & 30.0 & 46.0 & 4.140 & .989 \\
\hline $\begin{array}{l}\text { We use cashflow } \\
\text { statements in making } \\
\text { investment decision }\end{array}$ & 8.0 & 12.0 & 4.0 & 30.0 & 46.0 & 3.940 & 1.315 \\
\hline
\end{tabular}

Results in Table 1 answer the question on the application of accounting information in making investment decisions at BPR Atlasmara. Results in Table 1 show the use of income statements in making decisions related to investment (mean of 4.180), use of balance sheet in making an investment decision (mean of 4.140), and use of cash flow in making an investment decision (means of 3.940).

Meanwhile, significant discrepancies were observed on the balance sheet (stdev of .989), income statement (stdev of 1.003), and cash flow statements (1.315). The study assessed the level of effectiveness for investment decision-making at BPR Atlasmara. 
Table 1: Level of effectiveness for investment decision making at BPR Atlasmara

\begin{tabular}{|l|c|c|c|c|c|c|c|}
\hline \multirow{2}{*}{ Investment decision } & $\begin{array}{c}\text { Strongly } \\
\text { Disagree }\end{array}$ & Disagree & $\begin{array}{c}\text { Not } \\
\text { Sure }\end{array}$ & Agree & $\begin{array}{c}\text { Strongly } \\
\text { Agree }\end{array}$ & \multirow{2}{*}{ Mean } & Std \\
\cline { 2 - 7 } & $\%$ & $\mathbf{\%}$ & $\mathbf{\%}$ & $\mathbf{\%}$ & $\mathbf{\%}$ & \\
\hline $\begin{array}{l}\text { BPR Atlasmara's core } \\
\text { competitive advantage }\end{array}$ & 2.0 & 2.0 & 10.0 & 16.0 & 70.0 & 4.500 .909 \\
\hline $\begin{array}{l}\text { BPR Atlasmara's capital } \\
\text { rasing }\end{array}$ & 0.0 & 18.0 & 20.0 & 26.0 & 36.0 & 3.800 & 1.124 \\
\hline $\begin{array}{l}\text { BPR Atlasmara's fixed } \\
\text { asset }\end{array}$ & 0.0 & 40.0 & 20.0 & 28.0 & 48.0 & 4.200 & .903 \\
\hline
\end{tabular}

Table 2 results demonstrated that BPR Atlasmara's core competitive advantage (mean of 4.500), BPR Atlasmara's capital raising (mean of 3.800), BPR Atlasmara's fixed asset (mean of 4.200) were realized at BPR Atlasmara. The study found that the majority of the mean was between 3.8 and 4.5. The findings reveal the correlation between accounting information and investment decision. In this vein, it was established the relationship between accounting information (income statement, balance sheet, cash flow statement) and investment decision (core competitive advantage, capital raising, fixed asset).

Table 2: Correlation Analysis between accounting information and investment decision

\begin{tabular}{|l|l|c|c|c|}
\hline \multirow{2}{*}{$\begin{array}{l}\text { Income } \\
\text { Statement }\end{array}$} & $\begin{array}{c}\text { Core Competitive } \\
\text { Advantage }\end{array}$ & $\begin{array}{c}\text { Capital } \\
\text { Raising }\end{array}$ & $\begin{array}{c}\text { Fixed } \\
\text { Asset }\end{array}$ \\
\cline { 2 - 5 } & Pearson Correlation & $.231^{* *}$ & $.159^{* *}$ & $.174^{* *}$ \\
\cline { 2 - 5 } $\begin{array}{l}\text { Balance } \\
\text { Sheet }\end{array}$ & Sign.(2-tailed) & .006 & .043 & .014 \\
\cline { 2 - 5 } & $\mathrm{N}$ & 50 & 50 & 50 \\
\hline \multirow{2}{*}{$\begin{array}{l}\text { Cashflow } \\
\text { Statements }\end{array}$} & Pearson Correlation & $.274^{* *}$ & $.187^{* *}$ & $324^{* *}$ \\
\cline { 2 - 5 } & Sig.(2-tailed) & 0.039 & 0.035 & 0.032 \\
\cline { 2 - 5 } & $\mathrm{N}$ & 50 & 50 & 50 \\
\cline { 2 - 5 } & Pearson Correlation & $.854^{* *}$ & $.873^{* *}$ & $.750^{* *}$ \\
\cline { 2 - 5 } & Sig.(2-tailed) & 0.018 & 50 & 0.036 \\
\hline
\end{tabular}

*Correlation is significant at the 0.005 level

As reflected in Table 3, a positive correlation was found between the income statement and BPR Atlasmara core competitive advantage $\left(r=231^{* *}, \mathrm{p}=0.006\right)$, income statement, and BPR Atlasmara's capital raising $\left(\mathrm{r}=.159^{* *}, \mathrm{p}=0.043\right.$, income statement, and BPR Atlasmara fixed asset $\left(\mathrm{r}=.174^{* *}=0.014\right)$. Results demonstrated that a positive correlation between the balance sheet and core competitive advantage $\left(r=.274^{* *}, \mathrm{p}=0.039\right)$, balance sheet, and capital raising $(\mathrm{r}=.187, \mathrm{p}=0.035)$ balance sheet and fixed asset $(\mathrm{r}=.324$, $\mathrm{p}=0.032$ ). Furthermore, it was evidenced, a positive correlation between cashflow statements and core competitive advantage $\left(\mathrm{r}=.854^{* *}, \mathrm{p}=0.018\right)$, cashflow statements and capital raising $\left(\mathrm{r}=.873^{* *}, \mathrm{p}=0.035\right)$, cashflow statements and fixed asset $\left(\mathrm{r}=.750^{* *}, \mathrm{p}=.0 .036\right)$. All the above, relationships are positively correlated given that the $p$-value was $<0.005$ proposing that an enhancement in information accounting leads to an effective 
investment decision. The research performed a multilinear regression to evaluate the effects of the independent variable on the dependent variable.

Table 3: Coefficient of Determination

\begin{tabular}{|l|c|c|c|c|c|}
\hline \multirow{2}{*}{ Model } & \multicolumn{2}{|c|}{ Unstandardized Coefficients } & Standardized Coefficients & $\mathbf{t}$ & Sig. \\
\cline { 2 - 6 } & $\mathbf{B}$ & Std. Error & Beta & & \\
\hline Income statement & 0.752 & 0.1032 & 0.152 & 4.223 & .0192 \\
\hline Balance sheets & 0.487 & 0.3425 & 0.054 & 3.723 & .0269 \\
\hline Cashflow statements & 0.545 & 0.2178 & 0.116 & 3.936 & .0251 \\
\hline
\end{tabular}

The study shows that for all accounting information parameters such as income statements, balance sheets, and cash flow statements to be constant zero, the investment decision will remain the same. Data assessed evidenced that variation in using income statements will affect 0.752 investment decisions, a unit increase in using balance sheets will increase the effectiveness in investment decision by 0.487 , while a unit increase in cashflow statements will lead to a 0.545 increase in effectiveness for an investment decision. This implies that the income statement is more to increase investment decisions followed by cashflow statements and balance sheets.

Results concur with the observation of Berisha (2012). Findings reveal that one of the primary responsibilities of management to the investors is to give a standardized financial statement evaluated and authenticated by a qualified auditor. It concludes that there is a relationship between accounting information and investment decision, Results shows the use of income statements in making decision-related to investment (mean of 4.333), use of balance sheet in making an investment decision (mean of 3.666), and use of cashflow in making an investment decision (means of 4.000).

Results indicate that the relationship is positively correlated given that the $\mathrm{p}$-value was $<0.005$ proposing that an enhancement in accounting information leads to an effective investment decision. The research performed a multilinear regression to evaluate the effects of the independent variable on the dependent variable. The study shows that for all accounting information parameters such as income statements, balance sheets, and cash flow statements to be constant zero, the investment decision will remain the same. Data assessed evidenced that variation in using income statements will affect 0.752 investment decisions, a unit increase in using balance sheets will increase the effectiveness in investment decision by 0.487 , while a unit increase in cashflow statements will lead to a 0.545 increase in effectiveness for an investment decision. This implies that the income statement is more to increase investment decisions followed by cashflow statements and balance sheets.

\section{Recommendations}

Based on the findings, the following recommendations are proposed. There is an opportunity to increase the percentage of using accounting information on investment decisions at BPRAtlasmara. Commercial banks should use accounting information 
always to increase the accuracy of their investment decision. BPR Atlasmara should increase the percentage of using accounting information for setting accurate objectives. The study also recommends that BPR Atlasmara should increase the use of accounting information on investment decisions based on human resources to increase the accuracy and effectiveness of the investment decision. The study recommends that BPR Atlasmara should consult the accounting information before investment decisions, and also it is recommending that all interested parties to accounting information should use required financial ratios analysis for an investment decision. Finally, the success or failure of any investment decision depends on accounting information.

\section{Conclusion}

From the introductory part, results show that core competitive advantage (mean of 4.50), BPR capital raising (mean of 4.33), fixed asset (mean of 3.33) were realized at BPR Atlasmara. The study found that the majority of the mean was between 3.5 and 5.0.

The study revealed that accounting information performs a crucial role in investment decisions which was shown to be a major force in the investment decision. This is achieved by the best fundamental concept of accounting suitable for each commercial bank. The study felt that accounting information plays a vital role in making an effective, accurate, and significant investment decision. The study found out the problems of the accounting system faced by BPR Atlasmara.

The study proves that accounting information was used by BPR Atlasmara significantly and the problem of using an accounting system is poor. It is a satisfactory result for a commercial bank. Since all commercial banks still face technological changes from within the bank which results in increasing uncertainty. The issue is concerning with the accounting information and another publicly disclosed document that were created important policy issues. In particular, incorrect information could affect the decision-making on investment.

\section{Conflict of Interest Statement}

James Hodari declares that he has no conflict of interest.

\section{About the Author}

Hodari James is a Rwandan by nationality who was born on 18 Nov 1983. He is currently a student at Chhatrapati Shahu Ji Maharaj University, Kanpur in India, pursuing his PhD Program. He has been a lecturer at East African University-Rwanda in management. His area of interest and research is in management specifically in accounting, finance, marketing and general management. 


\section{References}

Berisha, V., N. (2012). Standardization of accounting in Kosovo, British Journal of Economics, Finance and Management Sciences, Vol. 4 No. 1, pp. 11-17.

Luminita, R., 2014. Is it Important the Accounting Model Used by the Economic Entity in Making Decisions by the Users of the Information? Points of View. Economic Science Series, 23(1), pp. 669-677.

Busara, E. (2012). Financial analysis auditing and Governance, London: Amazon.

Hall, M. (2010). Accounting information and managerial work. Accounting, Organizations and Society, 35(1), 301-310

Handayani, B. D. (2011). Affecting Factors of the use of accounting information for small and Medium Enterprises, Vol. 11 No. 1, pp. 50-67.

Richard, B. \& Stewart, M. (2010). Principles of Corporate Finance, New York: McGraw-Hill.

Bebeşelea, M., 2014. Accounting Information and its Users. A Study of the Supply and De- mand of Accounting Information in Romania. Economics, Management, and Financial Markets, 9(4), pp. 150-157.

Xhelili, K,. F., \& Berisha, V., N. (2015). Role of SMEs in the Economic Development., Istanbul, $9^{\text {th }}$ International Scientific Conference.

Silviu-Virgil, C., 2014. The Importance of the Accounting Information for the Decisional Process. Economic Science Series, 23(1), pp. 593-603. 
Authors will retain copyright to their published articles agreeing that a Creative Commons Attribution 4.0 International License (CC BY 4.0 ) terms will be applied to their work. Under the terms of this license, no permission is required from the author(s) or publisher for members of the community to copy, distribute, transmit or adapt the article content, providing a proper, prominent and unambiguous attribution to the authors in a manner that makes clear that the materials are being reused under permission of a Creative Commons License. Views, opinions and conclusions expressed in this research article are views, opinions and conclusions of the author(s). Open Access Publishing Group and European Journal of Management and Marketing Studies shall not be responsible or answerable for any loss, damage or liability caused in relation to/arising out of conflict of interests, copyright violations and inappropriate or inaccurate use of any kind content related or integrated on the research work. All the published works are meeting the Open Access Publishing requirements and can be freely accessed, shared, modified, distributed and used in educational, commercial and non-commercial purposes under a Creative Commons Attribution 4.0 International License (CC BY 4.0). 